\title{
Continued pursuit of evidence-based indications and the optimal operation for pediatric valve-sparing aortic root replacement
}

\author{
Joseph B. Clark, MD
}

From the Division of Pediatric Cardiac Surgery, Department of Pediatrics, Penn State Children's Hospital, Hershey, Pa.

Disclosures: Author has nothing to disclose with regard to commercial support.

Received for publication Oct 3, 2018; accepted for publication Oct 4, 2018; available ahead of print Nov 7, 2018. Address for reprints: Joseph B. Clark, MD, 500 University Dr, H085, Hershey, PA 17033 (E-mail: jclark7@ pennstatehealth.psu.edu).

J Thorac Cardiovasc Surg 2019;157:1112-3

$0022-5223 / \$ 36.00$

Copyright (c) 2018 by The American Association for Thoracic Surgery

https://doi.org/10.1016/j.jtcvs.2018.10.007

With this sentinel contribution, the Johns Hopkins group has again updated the preeminent experience with valvesparing aortic root replacement in children. ${ }^{1}$ As acknowledged in the report, the establishment of data-driven, evidence-based surgical indications remains elusive. Because of their history of leadership in the field, many will look to these authors for guidance regarding the criteria for operative intervention. In this report, they have presented their thresholds for surgery according to size, growth rate, and disease type. Nevertheless, the hard evidence to support these recommendations is limited, and such data might be difficult to obtain. Aortic root aneurysms are rare in children, curbing sample size and statistical power, and hampering the ability to draw strong conclusions. Further, with the currently low anticipated risk of surgical mortality, the opportunity might have passed for prolonged nonoperative surveillance of these aneurysms, especially at potentially threatening dimensions. Moving forward, it might therefore be increasingly difficult to characterize the unrepaired natural history of this disease and calculate its relative attendant risks.

With accruing experience, the surgical technique at Johns Hopkins for valve-sparing root replacement has evolved. ${ }^{2}$ Initially favored, the remodeling procedure has been abandoned because of a dissatisfying incidence of annular dilation, aortic insufficiency, and need for valve replacement. Consequently, the reimplantation procedure using a Dacron graft with prefashioned sinuses has been adopted. Because pseudoaneurysm development was observed in a subset of patients primarily with Loeys-Dietz syndrome, further specific technical modifications have been recommended for these cases such as the placement of additional subannular anchoring sutures. . $^{2,3}$

The study has some limitations. Although this robust and lengthy series spans 2 decades, the median follow-up duration is $<5$ years. Because of the probable quaternary referral pattern of the series, an increased proportion of long-

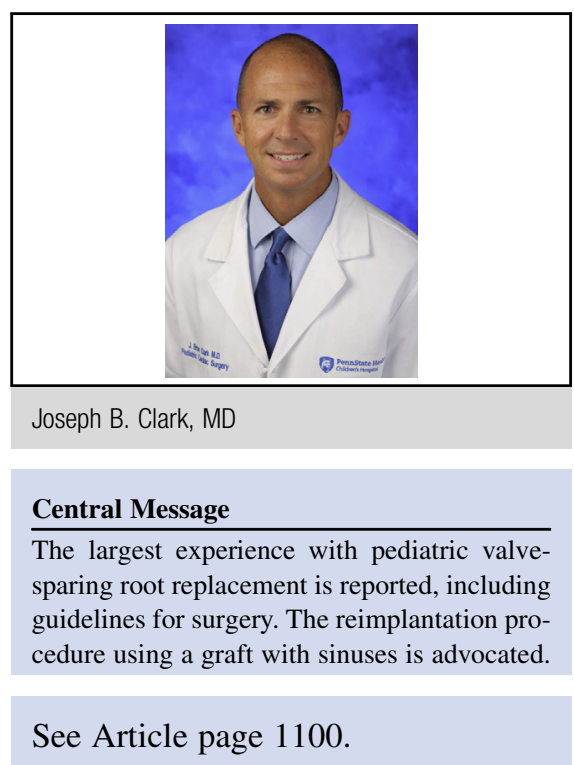

distance patients might have helped contribute to the loss of approximately one-third of patients from follow-up by the first year after surgery. This early attrition arguably compromises the ability to achieve a full and accurate description of late outcomes. Although the report again reasserts the superiority of the reimplantation technique, this conclusion must be tempered by the noncontemporaneous nature of the cohorts and the small number of patients in the remodeling group. Nevertheless, the present results are consistent with most studies, which have shown improved durability of the reimplantation procedure.

Finally, the preferred graft design for valve-sparing root replacement remains controversial. Even as this study corroborates other reports showing good results using a graft with prefabricated sinuses, ${ }^{4}$ others have reported large series with similarly favorable outcomes using straight grafts without sinuses. 5 Intuitively, the presence of sinuses would be expected to produce a more physiologic flow pattern with more natural movement of the aortic valve cusps. However, this theoretical advantage has not yet been conclusively shown to translate into improved valve longevity. Although advanced imaging studies do show improved flow characteristics when graft sinuses are present, $^{7,8}$ further research and clinical data will be needed in the quest for the optimal graft and aortic valvesparing operation. 


\section{References}

1. Fraser CD III, Liu RH, Zhou X, Patel ND, Lui C, Pierre AS, et al. Valve-sparing aortic root replacement in children: outcomes from 100 consecutive case. J Thorac Cardiovasc Surg. 2019;157:1100-9.

2. Vricella LA, Cameron DE. Valve-sparing aortic root replacement in pediatric patients: lessons learned over two decades. Semin Thorac Cardiovasc Surg Pediatr Card Surg Аnпu. 2017;20:56-62.

3. Liu RH, Fraser CD III, Zhou X, Cameron DE, Vricella LA, Hibino N. Pseudoaneurysm formation after aortic valve sparing root replacement in children with Loeys-Dietz syndrome. J Card Surg. 2018;33:339-43.

4. De Paulis R, Chirichilli I, Scaffa R, Weltert L, Maselli D, Salica A, et al. Longterm results of the valve reimplantation technique using a graft with sinuses. J Thorac Cardiovasc Surg. 2016;151:112-9.

5. David TE, David CM, Feindel CM, Manlhiot C. Reimplantation of the aortic valve at 20 years. J Thorac Cardiovasc Surg. 2017;153:232-8.

6. Shrestha ML, Beckmann E, Abd Alhadi F, Krueger H, Meyer-Bockenkamp F, Bertele S, et al. Elective David I procedure has excellent long-term results: 20year single-center experience. Ann Thorac Surg. 2018;105:731-8.

7. Oechtering TH, Hons CF, Sieren M, Hunold P, Hennemuth A, Huellebrand M, et al. Time-resolved 3-dimensional magnetic resonance phase contrast imaging (4D Flow MRI) analysis of hemodynamics in valve-sparing aortic root repair with an anatomically shaped sinus prosthesis. J Thorac Cardiovasc Surg. 2016; 152:418-27.

8. Gaudino M, Piatti F, Lau C, Sturla F, Weinsaft JW, Weltert L, et al. Aortic flow after valve sparing root replacement with or without neosinuses reconstruction. J Thorac Cardiovasc Surg. July 27, 2018 [Epub ahead of print]. 